examples of what works and what doesn't. The program will provide attendees with a real "nuts" and "bolts" discussion of what they need to do to get their projects off the ground.

This program will detail what a hybrid operating room is; what it can accomplish for the hospital, medical personnel, and patients; and will also provide a road map on how to install such an operating room at a hospital.

Target Audience:

- Hospital C-Suite Executives (CEO, CFO, COO, CMO)

- Thoracic Surgeon Leaders

- Directors of Surgery

- Directors of Operating Room

- Directors of Materials Management/Purchasing

- Facility Managers

- Nursing Leadership

Topics Covered:

- How To Convince Your Hospital Administrators to Fund a Hybrid OR

- How to Put the Team Together (Team Composition)

- Where Does the Hybrid OR Fit in a World of ValueBased Reimbursement?

- Building the CT ICU of the Future

ICU of the FUTURE

Interactive Exhibit

May 8-10, 2011

\section{Program Directors}

Robert N. Sladen, MD

Columbia University

Neil A. Halpern, MD

Memorial Sloan-Kettering Cancer Center

New for 2011, AATS members will be able to see firsthand what the future holds for cardiothoracic surgical critical care at the ICU of the Future display.

Located on the exhibit floor between the Cardiac and the General Thoracic Operating Rooms of the Future, the CT ICU of the Future will showcase cutting-edge equipment and the latest technological advances in imaging, advanced information technology, and critical care medicine used in cardiothoracic surgical critical care. In addition to stateof-the-art instruments for monitoring, treatment, and patient care, the display will also feature everything from smart beds and smart glass (used for patient privacy), to the latest in wireless technology, to innovations in ICU design and layout.
To register and reserve housing for the Annual Meeting or for additional information please visit www.aats.org or contact:

\section{American Association for Thoracic Surgery}

900 Cummings Center

Suite 221-U, Beverly, MA, USA 01915

Telephone: +1 (978) 927-8330

Fax: + 1 (978) 524-8890

E-mail: meetings@aats.org

\section{AATS Meetings and Sponsored Events www.aats.org}

February 10-13, 2011

11th Annual International Symposium on Congenital Heart Disease*

Renaissance Vinoy Resort

St. Petersburg, Florida

March 3, 2011

In Vivo Animal Models Course

Bethesda, Maryland

March 4, 2011

Grant Writing Workshop

Bethesda Marriott

Bethesda, Maryland

May 5-6, 2011

Mitral Conclave

Sheraton New York Hotel and Towers

New York, New York

May 7-11, 2011

AATS 91st Annual Meeting

Pennsylvania Convention Center

Philadelphia, Pennsylvania

May 26, 2011

AATS/ASCVTS Postgraduate Course*

Hilton Phuket Arcadia Resort \& Spa

Phuket, Thailand

September 8-10, 2011

International Society for Rotary Blood Pumps Annual Meeting*

Marriott Downtown

Louisville, Kentucky

October 20-21, 2011

7th Triennial Brigham Cardiac Valve Symposium*

Fairmont Copley Plaza Hotel

Boston, Massachusetts

*Co-sponsored by AATS 